\title{
The Correlation Between Spiritual Practices And Foreign Language Achievements Among Students
}

\author{
Afandi Yusoff ${ }^{1}$, Nik Mohd Rahimi Nik Yusoff ${ }^{1}$, *Harun Baharudin ${ }^{1}$ \\ Faculty of Education, Universiti Kebangsaan Malaysia, (UKM), 43600 Bangi, Selangor, Malaysia ${ }^{1}$ \\ *Corresponden author: harunbaharudin@ukm.edu.my
}

\begin{abstract}
Students are often faced with physical and psychological challenges when learning foreign languages. Besides having to need a delineated physical willingness, they also require spiritual support that can improve the accomplishments in that languages. This study aims to identify the levels of spiritual practices and the correlation in students' achievements in Arabic as a foreign language. This quantitative survey used questionnaires on spiritual practices and end-of-year results of Arabic language. 399 students of Religious Secondary Schools in Malaysia were chosen as respondents. Research findings showed that the level of spiritual practices were high, yet the achievements was moderate. There was a significant correlation between spiritual practices and achievements in Arabic language. The findings indicated that spiritual practices were to help one's performance in learning foreign languages. Therefore, the research implication is that the absorbance of spiritual practices in curriculum and teachings must be done in order to obtain good Arabic language achievements.
\end{abstract}

Keywords: Psychological, Spiritual Practices, Foreign Languages, Students’ Achievements, Arabic Language Learning Article Received: 18 October 2020, Revised: 3 November 2020, Accepted: 24 December 2020

\section{Introduction}

One of the reasons to execute foreign languages learning or the second languages is for communication and to understand the meaning of the languages (Ahmad Muradi, 2013; Azman \& Soon, 2010). Learning foreign languages is different than learning the language of our mother tounge, in which foreign languages are learnt at any academic institutions, whereby mother tounge acquisition is done informally or naturally at a very young age. One of the foreign languages learnt at schools and universities is Arabic language.

Learning foreign languages including Arabic language deals with a challenging responsibility in mastering the language. This is due to the fact that there are challenges and obstacles, for example attitudes and psychology of the students (Ashinida, 2013; Azman \& Soon, 2010). In education, psychology is a scientific knowledge related to feelings, soul, mental and inner behaviourism of an individual. Among the factors which resolve around psychology are motivation, self-efficacy, anxiety and etc. (Skehan, 1989). These psychological factors play an important role in influencing the students' achievements in learning. According to (Spielberger \& Donald, 1983) these psychological factors can lead to certain actions and emotional consciousness which later on drive individuals to succeed the learning mastery of the language.

Based on the observations on the previous researches, it is noticeable that these psychological factors have effects on the students' academic achievements especially in the learning of foreign language specifically Arabic language as stated in the research by Afandi, Nik Mohd Rahimi, \& Harun, (2019) and Abdullah, Nik Farhan, Che Radiah, \& Wan Muhammad, (2017) relating to anxiety, by Ghazali, Nik Mohd Rahimi, \& Parilah, (2010) on motivation, by Kamarul Shukri, (2014) relating to metaphysics strategies and by Nik Hanan, Nik Farhan, Nadwah, \& Mahmud, (2013), relating to self-efficacy.

Essentially, determination and adequate willingness in terms of physical and emotional endurances are prominently required during the process of learning the language which is carried out (Abd Aziz, Mohamad Fauzi, \& Mohamad Faisal, 2015). Students should also possess a 
strong will power from within themselves in mastering and uplifting their capabilities in language learning. Among the driving factors which can influence a student's achievements in learning is religious involvements or spiritual practices (Salasiah Hanin, Ermy Azziaty, Rosmawati, \& Zainab, 2012). Meaning to say, spiritual practices can assist in improving students' academic accomplishments at schools. This is further explained in the researches by Salasiah Hanin et al., (2012) and Hodge \& Cuddeback, (2010) which found that religious involvements were significantly related to some variables including academic, social behaviours and self-esteem. This is true also in the research done by Kamarul Shukri, (2014) among Arabic language students at a university in Terengganu, which discovered that there was significant relation between the use of metaphysics strategies (spirituality) and language achievements.

Other than that, the function of language learning becomes more enhanced when the language itself is connected to religious elements. This is due to the fact that the accomplishments of several global communitees which were related to religions such as Latin, which was made the language of Gods by the Greeks and Sanskrit was the language of Veda for Hindu (Hisham al-Din, n.d.). The same goes to Arabic language which is actually the language of the Holly Quran in Islam. Spiritual practices in Islam and the learning of Arabic language is seen to have its own benefits and indirectly influencing the learning achievements of the language itself (Kamarul Shukri, Mohamed Amin, Nik Mohd Rahimi, \& Zamri, 2009). Thus, through the learning of Arabic language, the conviction and perseverance in upholding any spiritual practices of Islam are enforced and strengthened.

Arabic language learning has a closely linked to Islam. According to Ibn Taymiyyah, (1979), Arabic language is a part of Islamic affairs. This is because, to understand the Quran and Sunnah, a Muslim must fully master and comprehend the knowledge of Arabic language. Additionally, most spiritual practices such as reciting the Quran, performing prayers, Zikr or the devotional acts of repeating phrases of prayers to remember Allah and etc must be said in Arabic language (Nor Aziah, Mohd. Ismail, Kamarul Azmi, \& Mohd. Hanafi, 2017). The same goes to performing worship, religious ceremonies and Islamic jurisprudence (Muamalat) which are never separated from using Arabic language (Kamarul Shukri et al., 2009). Therefore, an obedient Muslim's spiritual practices are always using Arabic language; indeed, it has so much impact on the learning of the language.

The correlation between spiritual and achievements have been studied by some previous researchers like Fahri, (2010) on the quality of employees' social lives, and research by Jasour \& Maleki Avarsin, (2016) towards work quality, the study on spirituality and language learning achievements specifically was still not well expanded and discussed in the previous literature. Most previous researches mainly focussed on the conceptual discussions and academic achievements in general in which is not sufficient enough to be used as guidelines in foreign languages education especially Arabic language (Chin Mei Keong, 2015; Mohamad Muhaimin, 2017; Salasiah Hanin et al., 2012).

One of the researches connected to Arabic language learning found is a research by Kamarul Shukri, (2014) which investigated the relation in using metaphysics strategy as one of the strategies in language learning with the achievemenst in Arabic language. In this respect, researches on spiritual achievements in Arabic language need to be explored in depth through this research. Moreover, this type of research is enthralling in a way to analyse suitable Islamic approaches which are appropriate as an accelerator in handling Arabic language achievements. Undoubtedly, it is the only language of the Quran and holds a special place in the Muslims' hearts over the world, specifically Malaysia (Al Muhsin et al., 2020).

Subsequently, the purpose of this research is to identify the levels of spiritual practices and Arabic language achievements among National Religious Schools in Malaysia. Other than that, this research 
was done to study the correlation of students' spiritual practices and their achievements in Arabic language subject.

\section{Literature Review}

According to the Encyclopedia of Islam, spiritual is a translated word from Arabic language ruhani (Bearman, Bianquis, Bosworth, Donzel, \& Heinrich, 2004) Spirituality deals with humans' inner self and soul (Al-Ghazali, 2000). Spiritual is a practice and individual's life appreciation by a Muslim (Zin, Nurfahiratul, \& Rohaya, 2018). This spiritual can influence changes upon individuals towards excellence in life including learning (A1Ghazali, 2000; Solichin \& Muhlis, 2020).

In an Islamic context, spirituality is closely related to living activities based on religion which makes Islam as a way of life from the aspects of aqidah (creed), ibadah (performimg worship) and akhlak (morals) (Zin et al., 2018). Every Muslim individual has to make aqidah as the guidelines and rules in life. Other than that, noble morals must also be practiced in order to prevent forbidden deeds or behaviours such as shirk which is the sin of ascribing to, or the establishment of, partners placed beside Allah, snobbery and envy. In other words, essentially spiritual concept in Islam is the inner- self of an individual, however this spirituality is also considered to be covering all aspects of life whether it is spiritual or physical (Bearman et al., 2004; Rafiza, Jaffary, Ahmad Sunawari, \& Zaizul, 2014). Through this spirituality, every Muslim is driven to the right path and consequently achieving the main goals of humans' existence on earth (Zin et al., 2018).

Besides overcoming conflicts of humans' well being of the soul and spirituality, spiritual practices can also contribute to an individual's accomplishments. Through the involvement of spiritual elements in every day's actions, it could bring effects towards an individual social competency as mentioned in Graham, Furr, \& Flowers, (2001) research and French, Eisenberg, Vaughan, Purwono, \& Suryanti, (2008). In addition, spiritual wellness is also believed to be able to bring impact to the work quality of a person. This was proven by Jasour \& Maleki Avarsin, (2016) through their research on 647 employees of 8 faculties at the University of Tabriz, Iran. Research findings showed that there is a correlation between spiritual intelligence and work quality achievements. The same goes to the improvement in teacher trainees quality at Malaysian Teachers Training Institute as stated in the research by Chin Mei Keong, (2015). It is also believed that spiritual intelligence that exists among employees of an organisation will help to improve that particular organisation (Ling, Singh, \& Arumugam, 2020). Similarly, a spiritual is able to deal with language anxiety (Afandi, Nik Mohd Rahimi, \& Harun, 2020). Also a spiritual approach to counseling is able to solve client problems as found in the study of Hanin Hamjah et al., (2020). Other than that, in academic context, spirituality has a connection with learning field. High spirituality among academic practitioners such as teachers and students can actually bring effects towards their learning. Research by Campbell, (2010) on some educators has found that the correlation between spiritual and transformative learning is significant. The findings showed that this spirituality can be a prominent factor in the learning process. Meanwhile, research by Hodge \& Cuddeback, (2010) on the effectiveness of release time programmes, which involved religious education and morals outside the classes stated that the group of students who participated in the programmes did not have significant relation to the low academic scores. This means, students who participated in religious educations have potentials to gain scores and good results in their learning.

In language learning, spirituality has effects on the language achievements. The influence of spirituality on language learning generally becomes strong when the language itself is the language of ibadah specifically when the language is used in performimg worship towards God that is Arabic language (Kamarul Shukri et al., 2009; Nor Aziah et al., 2017). Therefore, confidence and perseverance in performing ibadah in Islam can affect the learning of Arabic language and 
subsequently mastering the language itself. This statement is enforced by the research finding by Kamarul Shukri, (2014). On the relation between the use of metaphysics strategies with the achievements in Arabic language. One of these strategies has the elements of Tauhid and Godliness through stimulations and religious practices (Kamarul Shukri, 2014). The research also stated that the use of metaphysics strategies have a linear relation with the level of Arabic language achievements.

The relation between spirituality and academic achievements was further explained through a research done by Salasiah Hanin et al., (2012) among students of Islamic Studies Faculty UKM. According to her, there were a few daily spiritual practices which helped in improving students' achievements such as qiamulail, sunnah prayers, reciting the Quran, congregation prayers, and Muhasabah (self reflection). Besides, spiritual practices are related to learning; for example saying a prayer before starting a lesson, being tawakkal (or whole reliance on Allah), redha (wholeheartedly accept what has been decreed by the Almighty) if facing failures and being grateful when obtaining success. These too can be an influence in the students' academic achievements. According to Al-Ghazali, (2000), soleh (pious) practices done by a Muslim can actually help in gaining certain knowledge. For that purpose this kind of spiritual practice is a tauhid manifestation (unification or oneness of God) including the care of syariat or law and morals (Ahmad Amri, Khairul Anwar, Hasnan, \& Firdaus Mohamad, 2017; Mohamad Muhaimin, 2017). These practices were always guarded by and became priority for the previous pious generations in their behaviours at all times (Jamiah et al., 2013).

\section{Method}

\subsection{Research Design}

This research design used quantitative approach as a form of survey. This survey method was purposely used to review the perceptions and to assess spiritual practices level among students. The method chosen was a cross-sectional survey and used questionnaires as a measuring tool to collect data (Creswell, 2014). Through this method, data collected gave complete descriptive information about respondents' perceptions and behaviourism. Thus, the process to analyse the information was made easier, quick and efficient (Gall, Gall, \& Borg, 2005).

\subsection{Respondents}

A total of 399 students in 10 Religious Secondary Schools were chosen as respondents of this survey. All respondents were the representatives of research populations which 6925 Form 4 students who learn Arabic language at Religious Secondary School all over Malaysia. These respondents were chosen based on multi stage cluster sampling method. For each cluster, samples were chosen systematically random. Meanwhile, the samples were determined by considering the sample size by Krejcie \& Morgan, (1970) and G*Power software. The respondents consisted of $176(44.1 \%)$ male students and 223 (55.9\%) female students.

\subsection{Instruments}

To measure the levels of spiritual practices among the respondents, this research used questionnaires which were adapted from a survey by Salasiah Hanin et al., (2012) which was related to spiritual practices and academic achievements. This survey consisted 3 main constructs which were daily spiritual practices, spiritual practices involving learning and pious practices. There were 22 items in the questionnaires on spiritual practices and 5 likert scales were used as well. Validity and reliability of the measuring for spiritual pratices were assessed too and agreed by some experts. After the pioneer survey was done, the Cronbach's Alpha coefficient value for the questionnaires on spiritual practices was 0.83 . This Cronbach's coefficient value gained showed us that the reliability of these questionnaires is high and all items have stability and can be accepted (Pallant, 2011; Sekaran \& Bougie, 2016). Meanwhile, to measure the level of the respondents' Arabic language achievement, this research referred to the end-of-year examination results of the current 
year reported by School Examinations Analysis System (KPM, 2011).

\subsection{Data Analysis}

Descriptive analysis in min value and standard deviation were used to determine the level of spiritual practices and the achievements of Arabic language among the students. Also, inference analysis using Pearson correlation tests was conducted in identifying the correlation of the two variables regarding spiritual practices and Arabic language achievements. In this research too, min value in the descriptive analysis was categorized into very low level of 1.01-1.80, low 1.81-2.60, moderate level referred to 2.61-3.40, high was 3.41-4.20 and very high was 4.21-5.00 (Tschannen-Moran, M. \& Gareis, 2004). Hence, students' levels of Arabic language achievements were categorised into 3 according to grading system which is set by the Ministry of Education, high level (100-70), moderate (69-50) and low (49-0).

\subsection{Findings}

Based on the research findings, spiritual practices among students who learned Arabic language were at a high level with min value of 3.58 and standard deviation of 0.370 . Specifically, these research findings are shown at Table 1. Based on the table, this research discovered that the median value was 3.6 and mode value of 3.6. All these values show that there was almost similarity which proved that this research data display a normal spread. (Pallant, 2011). This research also did not have normality problems since Skewness and Kurtosis values are $< \pm 2.000$, respectively 0.100 and 0.102 (Hair, Black, Babin, \& Anderson, 2010; Pallant, 2011). These findings potrayed that the students practiced good spirituality.

Table 1: Level of Spiritual Practices

\begin{tabular}{|l|l|l|l|l|l|l|l|}
\hline Variables & Min & S.D & Medium & Mod & Skewness & Kurtosis & Level \\
\hline Spiritual Practices & 3.58 & 0.37 & 3.6 & 3.6 & 0.100 & 0.102 & High \\
\hline
\end{tabular}

At the same time, students' Arabic language achievements was at the moderate level, in which overall min obtained by the students was 59.93 marks. Details of the achievements are shown in Table 2. Specifically, 112 students (28.1\%) achieved high level, 152 students (38.1\%) obtained moderate and 135 students $(33.8 \%)$ were placed at low. It is noticeable that the level group was the largest, representing $38.1 \%$ of the overall numbers.

Table 2: Arabic Language Achevements Level

\begin{tabular}{|c|c|c|c|c|}
\hline Level & Frequency & Percentage & Min & S.D \\
\hline Low & 135 & 33.8 & \multirow{2}{*}{56.93} & \multirow{2}{*}{17.63} \\
\hline Moderate & 152 & 38.1 & \\
\hline High & 112 & 28.1 & \\
\hline Total & 399 & 100 & \\
\hline
\end{tabular}

In order to measure the relation between spiritual practices and Arabic Language achievements of the students, Pearson Correlation test was carried out. After the preconditions to execute the Pearson correlation test were fulfilled, the findings of the test are shown in Table 3. Based on the table, the research findings showed that there was a positive significant correlation between spiritual practices and Arabic language achievements. The values show $\mathrm{p}=0.000 \quad(\mathrm{p}<0.05)$ whereas $\mathrm{r}=0.185$. The positive correlation found at the value of $r$ explains that the higher level of the students' spiritual practices is, the higher Arabic language achievements gets and vice versa. Therevore, 
these findings shown that spiritual practices can

language.

affect one's accomplishement in learning Arabic

Table 3: Correlation between spritual practices and Arabic Language Achievement

\begin{tabular}{|l|l|l|l|}
\hline Variables & $\mathrm{r}$ & $r^{2}$ & Sig. \\
\hline Spiritual practices and Arabic Language Achievement & .185 & .034 & .000 \\
\hline
\end{tabular}

\section{Discussion}

The research findings analysis displayed that spiritual practices were positioned at high level. This means, it explains that students who learn Arabic language perform spiritual practices very well. Therefore, it was clear that these students practiced spirituality daily and thus, their actions impacted on their learning and their lives. These findings also enhanced the National Education Philosophy in which to produce individuals who are well balanced in the aspects of intellectual, spiritual, emotions and physical. In addition, enhancing spiritual aspects based on the beliefs and obedience towards God. This matter also strengthens the effectiveness of spiritual programmes implemented at schools. The level of spiritual practices in this research are parallel to the research done by Angelo \& Vijay, (2019) which discovered that spiritual intelligence of the students in high schools or secondary schools in India was also high.

Besides, these findings are also in line with the research by Chin Mei Keong, (2015) which discovered that majority of the trainee teachers had high spiritual level. Meanwhile, research by Graham et al., (2001) towards university students on their spirituality also showed similar findings. In fact all researches related to spirituality towards students of all education levels such as schools, colleges or universities came up with almost the same findings. However, this particular research differs from the previous ones in term of research instrument. In this research, the researcher used the instrument adapted from the the research by Salasiah Hanin et al., (2012) and was based on the views of Imam Al-Ghazali, (2000), whereas most previous researches used the Western instrument of spiritual intelligence.
In general, the accomplishments of Arabic language among students or respondents were actually moderate. Majority of them scored grade $\mathrm{C}$ in the final examinations. The achievements obtained were seen as similar to the results of this subject in Malaysian Examinations Certificate (KPM, 2018). The findings of this research also support the research by Aisyah, Maimun, Harun, \& Mohd Sham, (2017) and by Kamarulzaman \& Wan Sakiah, (2018) which discovered the Arabic language mastery among Malaysian students was moderate. In fact, this moderate achievements did not only happen among the students at schools but universities students faced the same situation Noor Shamshinar, (2015) and Mohamad Ziyad \& Izudin, (2011). Nonetheless, this findings are not to be worried if compared to the findings by Nor Aziah et al., (2017) and Ghazali, Nik Mohd Rahimi, Parilah, Wan Haslina, \& Ahmed Thalal, (2012) which discovered that students learning Arabic language did not show good attainments. Therefore, this research has actually fulfilled the gaps of those many researches and contributes more details to the knowledge on the subject matter.

The Pearson correlation test results showed that there was a positive significant connection between spirituality and Arabic language achievements. This shows that the accomplishments of Arabic language can be influenced by spiritual practices. In other words , students who carry out frequent spiritual practices can actually at the same time accomplish well in the learning of Arabic language or vice versa. These findings fit very well with the view by AlGhazali, (2000) that one's reliance to Allah S.W.T will go through the purifying of soul in order to gain whatever success including in learning. A 
great student is one who excels in his academic as well as developing a strong and sturdy spirituality. The relation between spiritual practices with the prominent achievements were found regularised in the previous researches especially in the organisational administrative concept such as the research by French et al., (2008) and Fahri, (2010) which contemplated the connection between spiritual intelligence, competency and achievements of an organisation. The same was found in the researches by Jasour \& Maleki Avarsin, (2016) and Ling et al., (2020) which discovered that the higher one's spiritual intelligence is, the better his career performance. It is similar in academic context; this research finding has resemblances with the one done by Solichin \& Muhlis, (2020) which found the relation between religiosity with the students' motivation in Religious Education. Besides, past researches on spirituality and education gained the same finding as the one by Chin Mei Keong, (2015) on the quality of the teacher trainees, by Salasiah Hanin et al., (2012) on academic achievements of the university students and by Hodge \& Cuddeback, (2010) on the success potentials of school students.

Through the discussion of this research findings, obviously spiritual elements are capable to create positive impact towards the achievements in either career management context or academically. Indeed, spirituality is needed to obtain stature and quality in every aspect especially academic. It is therefore believed that this research has opened up an opportunity for the stake holders in language learning to take into consideration of this serious matter regarding spirituality. Arabic language is the language of a religion and the language of religious practices for Islam which needs thorough plannings and executions that must be done in intergrading spirituality in curriculum and the teaching and learning of Arabic language (Al Muhsin \& Ahmad, 2020).

To achieve success in the learning of Arabic language, teachers and school administrators must instil spirituality in every student. This should include daily spiritual practices, spiritual practices related to learning and religion. As well as putting a lot of efforts in learning Arabic language, students should also try to improve spirituality in themselves. They can benefit from spiritual programmes carried out at schools such as Usrah (Islamic group work approach), Al-Quran Tadabbur (Intellection) and SUMUR programme (Great Personality Programme). These programmes stress on the building of the students' morality from the aspects of Aqidah, Ibadah and Akhlak (Mardziyah \& Nurul Ilyana, 2018). Thus, the mastery of Arabic language will take place by itself.

This research involves the variables of spiritual practices and Arabic language achievements which are closely related to psychological factors. There is a need to execute follow through researches about the relations of Islamic spirituality and other psychological factors connected to education such as language anxiety, self-efficacy, motivation and etc. By widening the research scope, it will help to explained that religious approach can be the best solution to humans' conflicts, whether it is spiritual or physical (Al Muhsin et al., 2020). Besides, the limitations of this research are due to the students who learn Arabic language at Religious Secondary Schools only. Therefore, these findings are unable to make any generalisations on all students who learn the language all over Malaysia. It is recommended that the research respondents are widened to students with various backgrounds and other primary schools in Malaysia as well.

\section{Conclusion}

Based on the discussion of this research, it can be concluded that spiritual practices are able to assist in uplifting and improving the achievements of Arabic language as a foreign language. This spiritual approach must be taken seriously by teachers and other educators nowadays. Members of the society should not only consist of those who are intellectually capable but also those who have strong spirituality. Great students are those academically excellent and at the same time have vigorous foundation of spirituality to prevent them 
from anything negative or sinful. Hence, the efforts put in this research will be beneficial and function as a guide for the teachers teaching Arabic language. Based on this research, teachers will be able to consider Islamic spiritual approaches as the accelerator in uplifting the Arabic language students' achievements. In addition, Arabic language is the language of the Holly Quran and this language has a special place in the hearts of Muslims globally; Malaysia specifically.

\section{Acknowledgement}

We gratefully acknowledge the financial support provided by the Geran Dana Penyelidikan FPEND, GG-2019-026.

\section{References}

[1] Abd Aziz, M., Mohamad Fauzi, Y., \& Mohamad Faisal, K. (2015). Penerokaan Terhadap Elemen Kebimbangan Dalam Empat Kemahiran Bahasa Arab Dalam Kalangan Pelajar Institut Pendidikan Guru. In Prosiding Persidangan Kebangsaan Bahasa Arab (NCAL2015) (pp. 90-96).

[2] Abdullah, H., Nik Farhan, M., Che Radiah, M. P., \& Wan Muhammad, W. S. (2017). Mengapa Guru Pelatih Bimbang Untuk Bertutur Dalam Kelas Bahasa Arab? Jurnal Kemanusiaan, (15), 1-6.

[3] Afandi, Y., Nik Mohd Rahimi, N. Y., \& Harun, B. (2019). Kebimbangan Bahasa dan Hubungannya dengan Pencapaian dalam Bahasa Arab. Jurnal Pendidikan Malaysia, $\quad 44(2), \quad$ 1-9. https://doi.org/http://dx.doi.org/10.17576/J PEN-2019-44.02-01

[4] Afandi, Y., Nik Mohd Rahimi, N. Y., \& Harun, B. (2020). Amalan Kerohanian dan Kaitannya dengan Kebimbangan Bahasa dalam kalangan Penuntut Sekolah Menengah Kebangsaan Agama di Malaysia Secondary Schools in Malaysia. Islamiyyat, $\quad 42(1), \quad 57-63$. https://doi.org/doi.org/10.17576/islamiyyat $-2020-4201-07$
[5] Ahmad Amri, Z. A., Khairul Anwar, M., Hasnan, K., \& Firdaus Mohamad, H. (2017). Religiositi Sebagai Faktor Meditasi Tingkah Laku Kerja Muslim. Jurnal Hadhari UKM, 9(1), 141-156.

[6] Ahmad Muradi, M. A. (2013). Tujuan Pembelajaran Bahasa Asing (Arab) di Indonesia. Al-Maqoyis, I(Januari-Jun), 128-137.

[7] Aisyah, S., Maimun, A. L., Harun, B., \& Mohd Sham, K. (2017). Kepentingan pembelajaran motivasi bahasa arab dalam kalangan pelajar IPTA dari perspektif sorotan kajian. ASEAN Comparative Education Research Journal on Islam and Civilization (ACER-J), 1(2), 102-112.

[8] Al-Ghazali, A. H. M. B. A. (2000). Ihya' 'Ulum al-Din. (A. R. bin al-H. Al-'Iraqi, Ed.). al-Qahirah: Dar al-Taqwa li alTurath.

[9] Al Muhsin, M. A., Ahmad, N. Z., Sarudin, A., Muhammad, M. M., Othman, Z., Makki, S., \& Kassymoca, G. K. (2020). The Implementation of SCL in Teaching Arabic for Islamic Finance: A Dynamic Approach in Preparing For Education 4.0. International Journal of Psychosocial Rehabilitation. Vol. 24(9). p. 279 - 290.

[10] Al Muhsin, M. A., \& Ahmad, N. Z. (2020). The Emergence of Education 4.0 Trends in Teaching Arabic Islamic Finance Curriculum Design: A Case Study. International Journal of Psychosocial Rehabilitation. Vol. 23(4), p. 1019 - 1031.

[11] Al Muhsin, M. A., Mohd, K. N., Muhammad, M. M., Sarudin, A., Osman, Z., Makki, S., Etigani, M. A. M. A. (2020). THE CHARACTERISTICS OF PROPOSE ARABIC LANGUAGE MODULE FOR THE PURPOSE OF TOURISM: A CASE STUDY ON TOURISTS' MOSQUE IN KUALA LUMPUR. Jounal of Critical Review. Vol. $7(14), \quad$ p. $515 \quad-521$, DOI: http://dx.doi.org/10.31838/jcr.07.14.89. 
[12] Angelo, J., \& Vijay, C. (2019). Gender Wise Differences On Spritual Intelligence Among Senior Secondary School Students. International Journal of Education, 11(46229), 223-234.

[13] Ashinida, A. (2013). Demotivating Factors in the Arabic Language Clasroom: What Demotivates non-Muslim Malaysian Learners when it Comes to Learning Arabic? Procedia - Social and Behavioral Sciences, 93, 1652-1657. https://doi.org/10.1016/j.sbspro.2013.10.0 96

[14] Azman, C. M., \& Soon, G. Y. (2010). Situasi Pembelajaran Bahasa Asing Di Institut Pengajian Tinggi: Perbandingan Antara Bahasa Arab, Bahasa Mandarin Dan Bahasa Perancis. AJTLHE, 2(2), 920.

[15] Bearman, P. J., Bianquis, T., Bosworth, C. E., Donzel, E. Van, \& Heinrich, W. P. (2004). The Encyclopaedia of Islam. Central Asian Survey. Netherlands: Leiden Brill.

https://doi.org/10.1080/026349391084007 35

[16] Campbell, K. P. (2010). Transformative Learning and Spirituality: A Heuristic Inquiry into the Experience of Spiritual Learning. Tesis Dr. Fal, University of Capella.

[17] Chin Mei Keong. (2015). Kecerdasan Emosi Dan Kecerdasan Spiritual: FaktorFaktor Yang Mempengaruhi Dan Sumbangannya Ke Atas Kualiti Guru Pelatih. Tesis Dr. Fal,: Universiti Kebangsaan Malaysia.

[18] Creswell, J. W. (2014). Research Design: Qualitative, Quantitative and Mixed Methods Approach (4th ed.). California: SAGE Publication Inc.

[19] Fahri, K. (2010). Spirituality and Performance in Organizations: A Literature Review. Journal of Business Ethics, (June), 1-43. https://doi.org/10.1007/s10551-009-02515

[20] French, D. C., Eisenberg, N., Vaughan, J., Purwono, U., \& Suryanti, T. A. (2008). Religious Involvement and the Social Competence and Adjustment of Indonesian Muslim Adolescents. Developmental Psychology, 44(2), 597-611. https://doi.org/10.1037/00121649.44.2.597

[21] Gall, J. P., Gall, M. D., \& Borg, W. R. (2005). Applying Educational Research: A Practical Guide (5th ed.). Boston: Pearson/Allyn \& Bacon.

[22] Ghazali, Y., Nik Mohd Rahimi, N. Y., \& Parilah, M. S. (2010). Kebimbangan Ujian Dan Motivasi Dalam Kalangan Pelajar Kursus Bahasa Arab Dalam Konteks Kemahiran Lisan. Asean Journal of Teaching and Learning in Higher Education (AJTLHE), 2(2), 46-58.

[23] Ghazali, Y., Nik Mohd Rahimi, Parilah, M. S., Wan Haslina, W., \& Ahmed Thalal, H. (2012). Penggunaan Strategi Belajar Bersama Rakan Dalam Kalangan Pelajar Kursus Bahasa Arab Di Universiti Teknologi Mara ( UiTM ). Asia Pacific Journal of Educators and Education, 27(2012), 37-50.

[24] Graham, S., Furr, S., \& Flowers, C. (2001). Religion and Spirituality in Coping With Stress. Counseling and Values, 46(October), 2-13.

[25] Hair, J. F., Black, W. C., Babin, B. J., \& Anderson, R. E. (2010). Multivariate Data Analysis. Vectors (7th ed.). New Jersey: Pearson Prentice Education Hall. https://doi.org/10.1016/j.ijpharm.2011.02. 019

[26] Hanin Hamjah, S., Mohd Arifin, S. N. ., Ismail, Z., Mastor, K. ., Mohamad Rasit, R., Rahman, A., \& Zaizul. (2020). Islamic Spiritual Approach Developing a Positive Mindset in. International Journal of Innovation, Creativity and Change, 10(10), 644-665. 
[27] Hisham al-Din, K. (n.d.). Muhadharat fi 'ilm al-lughah. Makkah al-Mukarramah: Jami'ah Umm al-Qura.

[28] Hodge, D., \& Cuddeback, G. (2010). Release Time and Academic Outcomes: Does Releasing Students for Religious or Moral Education Negatively Affect Test Scores? Journal of the Society for Social Work and Research, 1(1), 56-65. https://doi.org/10.5243/jsswr.2010.5

[29] Ibn Taymiyyah, T. al-D. A. b. 'Abd al-H. (1979). Iqtida' al-sirat almustaqim. (M. H. Al-Fiqi, Ed.). Bairut: Dar al-Afaq alJadidah.

[30] Jamiah, M., Azimi, H., Sidek, M. N., Hasnan, K., Steven, E. K., \& Khairul Anwar, M. T. S. · F. (2013). Prinsip Pengukuran Religiositi Dan Personaliti Muslim. Journal of Psychology \& Human Development, 1, 36-43.

[31] Jasour, M., \& Maleki Avarsin, S. (2016). The relationship between attributional style and spiritual intelligence and job performance of employees of Tabriz University of Medical Sciences. Res Dev Med Educ., 5(2), 55-61. https://doi.org/10.15171/rdme.2016.012

[32] Kamarul Shukri, M. T. (2014). A closer look at metaphysic strategies and language. Asean Journal of Teaching and Learning in Higher Education (AJTLHE), 6(2), 24-36.

[33] Kamarul Shukri, M. T., Mohamed Amin, E., Nik Mohd Rahimi, N. Y., \& Zamri, M. (2009). Strategi Metafizik: Kesinambungan Penerokaan Domain Strategi Utama Pembelajaran Bahasa. GEMA Online Journal of Language Studies, 9(2), 1-13.

[34] Kamarulzaman, A. G., \& Wan Sakiah, W. N. (2018). Hubungan antara Sikap Membaca, Persekitaran Pembelajaran dan Amalan Pengajaran Guru dengan Pencapaian Kefahaman Bacaan Bahasa Arab Murid. Tinta Artikulasi Membina Ummah, 4(2), 24-38.
[35] KPM. (2011). Garis Panduan Pelaksanaan Modul Sistem Analisis Peperiksaan Sekolah (SAPS) Dalam Toolkit Pembangunan Sekolah. Putrajaya: Lembaga Peperiksaan Malaysia.

[36] KPM. (2018). Pengumuman Analisis Keputusan Sijil Pelajaran Malaysia Tahun 2018. Putrajaya: Lembaga Peperiksaan Malaysia.

[37] Krejcie, R. V, \& Morgan, D. W. (1970). Determining Sample Size for Research Activities Robert. Educational and Psychological Measurement, 38(1), 607610.

[38] Ling, F. C., Singh, J. S. K., \& Arumugam, T. (2020). Employee Contextual Performance, Social Intelligence, Spiritual Intelligence: A quantitative study in Malaysia. International Journal of Psychosocial Rehabilitation, 24(2), 968981.

[39] Mardziyah, A. A., \& Nurul Ilyana, M. A. (2018). Pengamalan Program Sahsiah Unggul Murid ( SUMUR ) Tehadap Penghayatan Akhlak Pelajar: Satu Tinjauan Awal. Journal of Advanced Research in Social and Behavioural Sciences, 10(2), 180-190.

[40] Mohamad Muhaimin, M. Z. (2017). Analisis Pengaplikasian Amalan Qalbu Dalam Pengajaran Dan Pembelajaran. Jurnal 'Ulwan, 1, 19-42.

[41] Mohamad Ziyad, M., \& Izudin, M. (2011). Penguasaan Asas Bahasa Arab Dalam Kalangan Pelajar PPISMP GSTT- PAI: Satu Kajian Kes. GEMA Online TM Journal Of Language Studies, 11(2), 1-22.

[42] Nik Hanan, M., Nik Farhan, M., Nadwah, D., \& Mahmud, A. W. (2013). Arabic Language Efficacy Questionnaire (ALEQ): Assessing self-efficacy and achievement. GEMA Online Journal of Language Studies, 13(1), 155-167.

[43] Noor Shamshinar, Z. (2015). Pelaksanaan Klinik Bahasa Arab Sebagai Wadah Penguasaan Bahasa Arab Di KUIS. E- 
Jurnal Pendidikan, Kolej Universiti Islam Antarabangsa Selangor, 2(1), 92-102.

[44] Nor Aziah, J., Mohd. Ismail, M., Kamarul Azmi, J., \& Mohd. Hanafi, A. R. (2017). Pengajaran Dan Pembelajaran Bahasa Arab : Masalah Dan Cabaran. International Journal of Religion Research in Education, 1(2), 65-71.

[45] Pallant, J. (2011). SPSS Survival Manual: A step by step guide to data analysis using SPSS (4th ed.). Australia: Allen \& Unwin Book Publishers.

[46] Rafiza, M., Jaffary, A., Ahmad Sunawari, L., \& Zaizul, A. R. (2014). Perbandingan Religiositi Menurut Perspektif Islam dan Barat. In The 1st International Conference on Language, Literature, Culture \& Education (pp. 161-166).

[47] Salasiah Hanin, H., Ermy Azziaty, R., Rosmawati, M. R., \& Zainab, I. (2012). Perkaitan Amalan Spiritual Dengan Pencapaian Akademik Pelajar. Asean Journal of Teaching and Learning in Higher Education (AJTLHE), 4(2), 51-60.

[48] Sekaran, U., \& Bougie, R. (2016). Research Methods for Business: A Skill Building Approach. Wiley (7th ed.). United Kingdom: John Wiley \& Sons Ltd. https://doi.org/10.13140/RG.2.1.1419.312 6

[49] Skehan, P. (1989). Individual Differences In Second-Language Learning. London: Edward Arnold.

[50] Solichin, M. M., \& Muhlis, A. (2020). Correlation between Religiosity and Student Achievement Motivation in Islamic Education Science Students. International Journal of Innovation, Creativity and Change, 11(10), 406-420.

[51] Spielberger, \& Donald, C. (1983). Manual for the State-trait Anxiety Inventory. Palo Alto, CA: Consulting Psychologist Press. Stevick.

[52] Tschannen-Moran, M., \& Gareis, C. (2004). Principals sense of efficacy: Assessing a promising construct. Journal www.psychologyandeducation.net of Educational Administration, 42, 573585.

[53] Zin, M. Z. M., Nurfahiratul, A. H., \& Rohaya, S. (2018). Kepentingan Amalan Religiositi Dalam Pembangunan Profesional. Borneo International Journal, 1(1), 20-26. 